\section{Impacts of Growth Substrate and Container Size on Cutting Production from 'Snow Angel' Coral Bells Stock Plants}

\author{
Shana G. Brown ${ }^{1}$ and James E. Klett ${ }^{1}$
}

ADDITIONAL INDEX WORDs. herbaceous perennial, Heuchera sanguinea, soilless media, vegetative propagation

\begin{abstract}
SUMMARY. Stock plant productivity is an important concern for growers of 'Snow Angel' coral bells (Heuchera sanguinea) because this variety produces a limited number of basal cuttings. The objective of the study was to determine the best growth substrate and container size combination to maximize productivity of stock plants. A secondary objective was to determine if the stock plant treatments influenced the rooting of vegetative cuttings. The study used three different container sizes $(2.8,11.4$, and $14.6 \mathrm{~L})$ and four commercial soilless substrates that were primarily composed of the following: bark, peat, and perlite (substrate 1); bark, peat, and vermiculite (substrate 2); bark, peat, and coarse perlite (substrate 3 ); and peat (substrate 4). Two stock plant experiments were conducted using the same 12 treatment combinations, and a subset of those stock plants was randomly selected for the rooting studies that immediately followed each stock plant experiment. Stock plants responded to substrate treatments differently depending on the batch of substrate in which they were grown. The most successful stock plants, which produced more cuttings per plant and per square foot, as well as larger cuttings, were those grown in substrate 3 (Expt. 1) and substrate 2 (Expt. 2). Regardless of the substrate, the highest number of cuttings per square foot was obtained from stock plants grown in 2.8-L containers, indicating that the smaller containers allow for the most efficient use of space when growing 'Snow Angel' stock plants for 6 to 8 months. The rooting of vegetative cuttings was successful (98\% to $100 \%$ of cuttings rooted after 4 weeks under mist) for all treatment combinations, although higher numbers of visible roots were produced during the second study and may be due to larger fresh weights of cuttings.
\end{abstract}

$\mathrm{T}$ he popular cultivar Snow Angel coral bells is a commercially important herbaceous perennial grown for its attractive white and green variegated foliage and bright pink flowers. To maintain the characteristic variegated foliage, 'Snow Angel' must be propagated by vegetative cuttings. Stock plants of this variety are often grown in containers for 1 to 2 years in greenhouses. Initially, container-grown stock plants produce more cuttings as the plants mature until they reach

Received for publication 22 Aug. 2019. Accepted for publication 14 Jan. 2020.

Published online 13 February 2020.

${ }^{1}$ Department of Horticulture and Landscape Architecture, Colorado State University, 301 University Avenue, Fort Collins, CO 80523-1173

Mention of a trademark, proprietary product, or vendor does not constitute a guarantee or warranty of the product by Colorado State University and does not imply its approval to the exclusion of other products or vendors that also may be suitable.

J.E.K. is the corresponding author. E-mail: jim.klett@ colostate.edu.

This is an open access article distributed under the CC BY-NC-ND license (https://creativecommons.org/ licenses/by-nc-nd/4.0/).

https://doi.org/10.21273/HORTTECH04495-19 a plateau often due to limited root space or shoot crowding, but the length of the plateau can be influenced by culture and management practices (Adam, 2005).

Light and air temperature have important roles in growth rates of stock plants because they act as cues and can trigger seasonal changes in development. In general, warmer temperatures will increase growth rates, but not without limits. Gibson and Cerveny (2005) recommended keeping stock plants in shade during the hottest months and maintaining greenhouse temperatures between 62 and $70{ }^{\circ} \mathrm{F}$ during the day and between 58 and $70^{\circ} \mathrm{F}$ at night to encourage maximum growth. Lighting duration and wavelength can also influence plant growth and development. The critical daylength for vegetative growth of coral bells is around $12 \mathrm{~h}$ and between 12 and $15 \mathrm{~h}$ for reproductive growth, although this taxon also requires a period of vernalization at $5^{\circ} \mathrm{C}$ for 9 to 10 weeks with subsequent long days to flower (Albrecht and Crockett, 1994).

Two cultural factors that affect growth parameters of stock plants are the containers and substrate in which they are grown. Although perennial growers often use the same substrate for most or all of their stock plants, the appropriateness of the substrate characteristics will vary with the plant species being grown (Ingram et al., 1993). The ideal growing substrate will depend on the species, and plants will perform best when grown in a substrate that mimics the species' natural habitat (Gabriel et al., 2009).

Container size can affect the morphological and physiological properties of plants, and the effects are often more pronounced in smaller containers (NeSmith and Duval, 1998). Growth of below-ground organs (such as roots) is tied to the growth of the aboveground tissues because they rely on each other for different substances. Roots rely on the shoots to provide carbohydrates and hormones such as auxins and gibberellins, but the shoots also rely on the roots for water, nutrients, and cytokinins (Tonutti and Giulivo, 1990). The environment within the growth substrate is extremely important for container-grown plants, but it may be even more important than the environmental conditions of the aerial parts of the plant because extreme temperature fluctuations of the root zone and more accelerated water depletion can occur under root restricted conditions (Poorter et al., 2012).

\begin{tabular}{llll}
\hline $\begin{array}{l}\text { Units } \\
\text { To convert U.S. to SI, } \\
\text { multiply by }\end{array}$ & U.S. unit & SI unit & $\begin{array}{l}\text { To convert SI to U.S., } \\
\text { multiply by }\end{array}$ \\
\hline 0.0929 & $\mathrm{ft}^{2}$ & $\mathrm{~m}^{2}$ & 10.7639 \\
3.7854 & $\mathrm{gal}$ & $\mathrm{L}$ & 0.2642 \\
2.54 & inch(es) & $\mathrm{cm}$ & 0.3937 \\
16.3871 & inch & $\mathrm{cm}^{3}$ & 0.0610 \\
1 & meq $/ 100 \mathrm{~g}$ & $\mathrm{cmol}^{3} \cdot \mathrm{kg}^{-1}$ & 1 \\
1 & $\mathrm{mmho} / \mathrm{cm}$ & $\mathrm{mS} \cdot \mathrm{cm}^{-1}$ & 1 \\
28.3495 & $\mathrm{Oz}$ & $\mathrm{g}$ & 0.0353 \\
1 & $\mathrm{ppm}$ & $\mathrm{mg} \cdot \mathrm{L}^{-1}$ & 1 \\
$\left({ }^{\circ} \mathrm{F}-32\right) \div 1.8$ & ${ }^{\circ} \mathrm{F}$ & ${ }^{\circ} \mathrm{C}$ & $\left({ }^{\circ} \mathrm{C} \times 1.8\right)+32$
\end{tabular}


Although very popular with consumers, 'Snow Angel' coral bells is difficult to propagate vegetatively in sufficient numbers to meet consumer demand (Plant Select Propagation Committee, unpublished). Low propagule numbers and low rooting percentages contribute to low production numbers reported by perennial growers interviewed in preparation for this experiment. To address these issues, a research project was designed to examine the effects of stock plant container size and growth substrate on the number and quality of vegetative cuttings produced as well as the rooting of cuttings from a subset of those stock plants.

\section{Materials and methods}

We conducted two stock plant experiments in Fort Collins, $\mathrm{CO}$ at Colorado State University's Horticulture Center in a double-wall polycarbonate greenhouse. Both stock plant experiments used the same 12 treatment combinations of substrate and container size to determine how these factors affected the number of harvestable cuttings that could be produced monthly.

Gulley Greenhouse in Fort Collins, $\mathrm{CO}$ provided us with rooted plugs grown in 72 -cell plant plug trays, which we transplanted to green plastic 4 -inch square pots $\left(48\right.$ inch $^{3}$ volume) on 7 Sept. 2016 for Expt. 1 and on 20 June 2017 for Expt. 2. During this establishment period, plants were grown in four treatment substrates: substrate $\mathrm{l}(\mathrm{Sl})$, composed of bark, coarse peatmoss, perlite, dolomitic and calicitic lime, and nonionic wetting agent $(\mathrm{BM}$ 7; Berger, Saint-Modeste, QC, Canada); substrate 2 (S2), composed of Canadian sphagnum peatmoss, bark, vermiculite, dolomitic limestone, bark ash, and wetting agent (Metro Mix 360; Sun Gro Horticulture, Agawam, MA); substrate 3 (S3), composed of bark, perlite and coarse perlite, Canadian sphagnum peatmoss, dolomitic limestone, and wetting agent (Metro Mix 820; Sun Gro Horticulture); and substrate 4 (S4), a peat substrate composed of blonde peatmoss, dolomitic limestone, and a wetting agent (Pindstrup, Ryomgaard, Denmark). Substrate analysis was conducted before planting as well as postgrowth (Table 1). After plants became established in the 4-inch containers and roots held the substrate together (20 Oct. 2016 for Expt. 1 and 13 Sept. 2017 for Expt. 2), plants were shifted into round black plastic 2.8-L (\#1), 11.4-L (\#3), or 14.6-L
(\#5) containers for the remainder of the study. After transplanting to the final container sizes, drip irrigation was installed using 0.5 -gal/h drip emitters (Xeric Bug; Rainbird, Azusa,CA). Plants were fertilized with $20 \mathrm{~N}$ 4.37P-16.6K fertilizer (Grow More, Gardena, CA) at $200 \mathrm{ppm}$ nitrogen (Table 2). Fertilizer was supplied using a liquid injector (model D14MZ2/14 GPM; Dosatron, Clearwater, FL), which provided nutrients with every irrigation, twice weekly for $30 \mathrm{~min}$. Supplemental water without fertilizer was applied between irrigation times only as needed to maintain plant health.

The goal was to give each plant the same amount nutrients to eliminate fertilizer as a variable and obtain a better understanding of the effects of container size. Although the biweekly fertigation was sufficient to saturate all container sizes, they have different container capacities; therefore, they cannot provide the same amount of water and nutrients to stock plants. Because the substrate in smaller containers tended to dry faster, the supplemental watering practices could have had an effect on the results of the study. Although containers on the south side of the bench were exposed to more sun and tended to dry out

Table 1. Substrate analysis before (pre) planting and after (post) growth of greenhouse-grown 'Snow Angel' coral bells stock plants of substrate 1 , substrate 2 , substrate 3 , and substrate $4 .^{\mathrm{z}}$

\begin{tabular}{|c|c|c|c|c|c|c|c|c|c|c|c|c|c|c|c|c|c|}
\hline & \multirow[b]{2}{*}{ Substrate } & \multicolumn{2}{|c|}{$\begin{array}{c}\text { Total } \\
\text { nitrogen } \\
(\%)\end{array}$} & \multicolumn{2}{|c|}{ OM (\%) } & \multicolumn{2}{|c|}{ Lime (\%) } & \multicolumn{2}{|c|}{$\begin{array}{c}\mathrm{pH} \\
\text { (paste) }\end{array}$} & \multicolumn{2}{|c|}{$\begin{array}{c}\mathrm{NH}_{4}: \mathrm{NO}_{3} \\
\quad \text { (ratio) }\end{array}$} & \multicolumn{2}{|c|}{ C:N (ratio) } & \multicolumn{2}{|c|}{$\begin{array}{c}\text { CEC (meq/ } \\
100 \mathrm{~g})^{\mathrm{y}}\end{array}$} & \multicolumn{2}{|c|}{$\begin{array}{c}\text { EC } \\
(\mathrm{mmho} / \\
\mathrm{cm})^{\mathrm{y}}\end{array}$} \\
\hline & & Pre & Post & Pre & Post & Pre & Post & Pre & Post & Pre & Post & Pre & Post & Pre & Post & Pre & Post \\
\hline \multirow[t]{3}{*}{ Batch 1} & $S 1$ & 1.13 & 0.20 & 65.5 & 55.7 & 0.5 & 0.06 & 6.1 & 6.3 & 0.02 & 1.25 & 30.9 & 72.1 & 77 & 10.33 & 1.3 & 1.0 \\
\hline & S2 & 2.27 & 0.13 & 44.7 & 33.0 & 0.9 & 0.52 & 6.3 & 5.4 & 0.83 & 1.32 & 13.0 & 76.19 & 59 & 10.21 & 0.8 & 1.9 \\
\hline & S3 & 0.40 & 0.14 & 52.5 & 45.3 & 0.45 & 0.18 & 5.6 & 5.3 & 0.01 & 1.14 & 83.8 & 123.7 & 69 & 9.80 & 2.1 & 0.5 \\
\hline \multirow{3}{*}{ Batch 2} & S2 & 0.10 & 3.77 & 32.4 & 17.0 & 0.26 & 0.60 & 3.8 & 4.7 & 1.41 & 1.90 & 55.23 & 9.0 & 4.3 & 2.0 & 1.7 & 1.4 \\
\hline & S3 & 0.14 & 3.01 & 43.7 & 34.7 & 0.47 & 0.22 & 3.8 & 5.3 & 1.31 & 1.87 & 73.51 & 11.3 & 5.14 & 2.0 & 1.9 & 1.2 \\
\hline & S4 & 0.30 & 2.78 & 59.7 & 17.7 & 0.47 & 0.31 & 4.7 & 5.8 & 1.22 & 1.89 & 41.25 & 18.8 & 11.4 & 3.0 & 2.4 & 0.9 \\
\hline
\end{tabular}

${ }^{\mathrm{z}}$ Substrate 1 (S1; primarily bark, peat, and perlite), substrate 2 (S2; primarily bark, peat, and vermiculite), substrate 3 (S3; primarily bark, peat, and coarse perlite), and substrate 4 (S4; primarily peat) for Expt. 1 and Expt. 2. Batch 1 used for Expt. 1 (2016 and 2017) and batch 2 used for Expt. 2 (2017) were tested for percent total nitrogen, percent organic matter $(\mathrm{OM})$, percent lime (CaCO3), $\mathrm{pH}$ using the paste method, ammonium-to-nitrate ratio (NH4:NO3), carbon-to-nitrogen ratio (C:N), cation exchange capacity (CEC), and electrical conductivity (EC).

${ }^{\mathrm{y}} 1 \mathrm{meq} / 100 \mathrm{~g}=1 \mathrm{cmol} \cdot \mathrm{kg}^{-1}, 1 \mathrm{mmho} / \mathrm{cm}=\mathrm{mS} \cdot \mathrm{cm}^{-1}$.

Table 2. Fertilizer analysis of $20 \mathrm{~N}-4.37 \mathrm{P}-16.6 \mathrm{~K}$ applied at a rate of $200 \mathrm{ppm}\left(\mathrm{mg} \cdot \mathrm{L}^{-1}\right)$ nitrogen with each irrigation to greenhouse grown stock plants of 'Snow Angel' coral bells twice weekly during Expt. 1 (2016 to 2017) and Expt. 2 (2017).

\begin{tabular}{lcccccccccc}
\hline Ammonium & Nitrate & Phosphate & Soluble potash & Boron & Copper & Iron & Manganese & Zinc & Molybdenum \\
\hline 8.0 & 12.0 & 10.0 & (\% by wt) & & & & \\
\hline & 120.0 & 0.02 & 0.05 & 0.11 & 0.06 & 0.05 & 0.005 \\
\hline
\end{tabular}


faster, this issue was accounted for by completely randomizing the plants on the benches. We also placed small platforms underneath the \#1 and \#3 containers to elevate them to the same height as the \#5 containers to prevent plant-to-plant shading.

Cuttings were harvested every 4 weeks for 3 consecutive months. During Expt. 1, cuttings were taken 22 Nov. 2016, 19 Dec. 2016, and 16 Jan. 2017. During Expt. 2, cuttings were harvested on 22 Aug., 18 Sept., and 16 Oct. 2017. On each harvest date, all suitable cuttings were harvested until no more suitable cuttings remained or one-third of the plant's canopy was removed. The protocol used to determine suitable cuttings was developed by combining a visual guide from Gulley Greenhouse (Fig. 1) and descriptions of ideal cuttings from perennial growers of this variety who we interviewed. By combining information from multiple growers, we were able to determine that the "best" 'Snow Angel' cutting is $\approx 0.25$ inches wide at the base with a 0.5 -inch to 1 -inch stem with no lateral shoots or dense, hardened basal tissue.

The first stock plant experiment was conducted from Oct. 2016 to Mar. 2017. We set the greenhouse to maintain temperatures between 62 and $70^{\circ} \mathrm{F}$ (day) and 58 to $70^{\circ} \mathrm{F}$ (night). These temperatures were

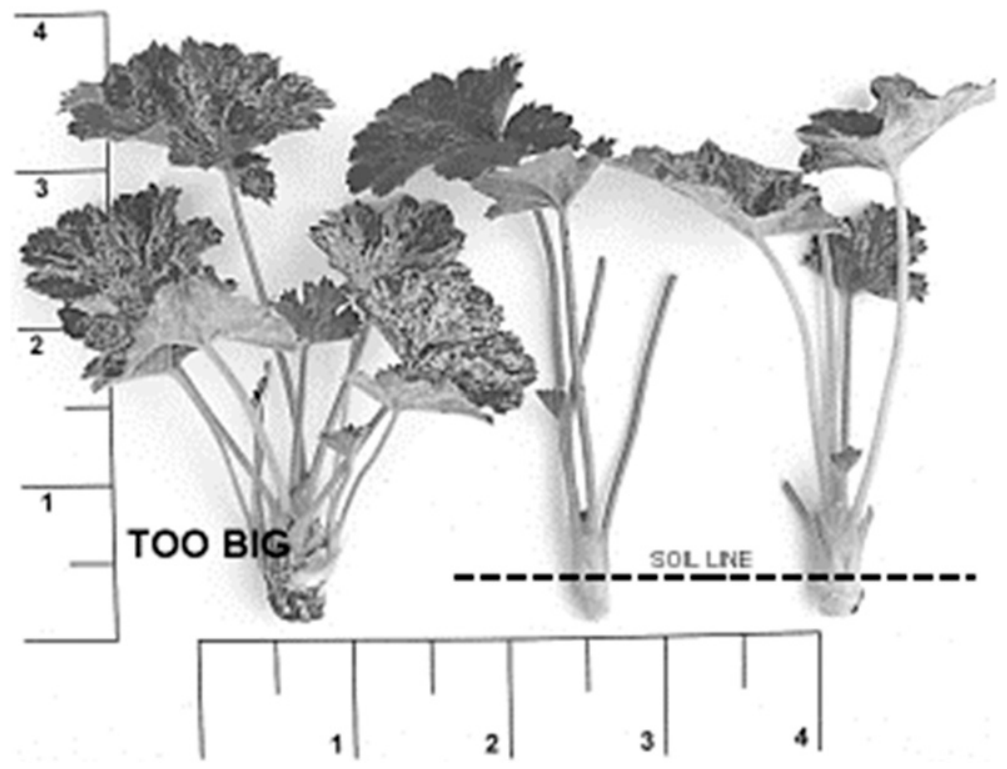

Fig. 1. Visual guide used for standardizing cuttings from 'Snow Angel' coral bells stock plants provided by Gulley Greenhouse, Fort Collins, CO. Cuttings on the right show ideal size and preparation for sticking. Measurements in inches $(1$ inch $=2.54 \mathrm{~cm})$. increased in late Dec. 2016 in an attempt to combat powdery mildew (Podosphaera sp.). The remainder of the experiment was completed with temperatures between 65 and $73{ }^{\circ} \mathrm{F}$ (day) and 61 to $73{ }^{\circ} \mathrm{F}$ (night). The average measured temperatures during the first experiment were $68.1^{\circ} \mathrm{F}$ (day) and $61.0^{\circ} \mathrm{F}$ (night) as determined by an aspirator (model M4821; Wadsworth Control Systems, Arvada, CO). Shade cloths providing $50 \%$ shade were set to close automatically only when needed for cooling. Supplemental lighting was provided by light-emitting diode (LED) fixtures (Green Power LED Toplighting Module DR/W MB 200-400V; Philips, Amsterdam, The Netherlands). Supplemental lighting fluctuated with the natural daylength and provided $\approx 90 \%$ red light and $10 \%$ blue light and operated daily from sunrise to sunset ( 9.5 to $11.5 \mathrm{~h}$ ).

The second stock plant experiment was conducted from July to Nov. 2017. Before starting the second stock plant experiment, greenhouse temperature set points were lowered to 62 to $68{ }^{\circ} \mathrm{F}$ (day) and 55 to $62{ }^{\circ} \mathrm{F}$ (night) in an attempt to suppress flowering in another research subject, 'Orange Carpet' trumpet mint (Zauschneria garrettii 'PWWG01S'), being grown in the same greenhouse. The average measured temperatures in the greenhouse during the second experiment were $66.6{ }^{\circ} \mathrm{F}$ (day) and $60.6{ }^{\circ} \mathrm{F}$ (night). Supplemental LED lighting was on daily from 5:00 AM to 9:00 PM during the second experiment, providing 16-h days. Shade cloths providing $50 \%$ shade were used at all times during the second experiment to help maintain lower air temperatures in the greenhouse.

Using a $3 \times 4$ factorial design, these experiments had two factors: substrate with four levels (S1, S2, S3, and S4) and container size with three levels (\#1, \#3, and \#5). We grew 10 stock plants in each of the 12 treatment combinations, resulting in 120 total experimental units. Response variables for the stock plant experiment included the average number of cuttings per plant, average number of cuttings per square foot, and average fresh weight per cutting. Although it is typical to present dry weights, average fresh weight per cutting is presented here because it is better for describing the quality of the cutting at the time of harvest.

The number of cuttings per square foot was calculated by dividing the average number of cuttings per plant by the area occupied by each container size allowing adequate space for growth. For this experiment, each plant was given 6 inches of space between containers to allow for air circulation and canopy expansion. Based on this measurement, \#1 containers occupied $1.0 \mathrm{ft}^{2}$ and \#3 and \#5 containers occupied $2.25 \mathrm{ft}^{2}$ because the containers were the same width. Analysis of cuttings per square foot was based on this spacing with the intention of discerning the value of using larger containers for commercial stock plant production.

The average fresh weight per cutting was calculated by dividing the total fresh weight of cuttings by the total number of cuttings harvested for each plant over the course of all three harvest dates.

The rooting of harvested cuttings was evaluated after the completion of each stock plant study and used a subset of stock plants used for the substrate and container size study. The first rooting study began in Apr. 2017 and ended in June 2017. The second rooting study was initiated in Dec. 2017 and ended in Feb. 2018. Four randomly selected stock plants were saved from each treatment combination of substrate and container 
Table 3. Number of cuttings harvested per plant from greenhouse-grown 'Snow Angel' coral bells stock plants averaged over three harvest dates within Expt. 1 (Oct. 2016 to Mar. 2017) and Expt. 2 (July to Nov. 2017) as influenced by four substrate treatments. ${ }^{\mathrm{z}}$

\begin{tabular}{llr}
\hline & \multicolumn{1}{c}{ Expt. 1 } & \multicolumn{1}{c}{ Expt. 2 } \\
\cline { 2 - 3 } Treatment & \multicolumn{1}{c}{ Cuttings [mean (95\% CI) } & no./plant] \\
\hline S1 $^{\mathrm{y}}$ & $5.8(5.4-6.1) \mathrm{c}^{\mathrm{x}}$ & $4.2(3.8-4.7) \mathrm{a}$ \\
S2 & $7.6(7.3-7.9) \mathrm{a}$ & $4.8(4.3-5.3) \mathrm{a}$ \\
S3 & $8.0(7.7-8.4) \mathrm{a}$ & $3.9(3.4-4.4) \mathrm{a}$ \\
S4 & $6.5(6.2-6.9) \mathrm{b}$ & $4.8(4.3-5.2) \mathrm{a}$ \\
$\# 1^{\mathrm{w}}$ & $7.3(7.0-7.6) \mathrm{a}$ & $3.7(3.3-4.2) \mathrm{b}$ \\
$\# 3$ & $6.7(6.4-7.0) \mathrm{b}$ & $4.6(4.2-5.0) \mathrm{a}$ \\
$\# 5$ & $7.0(6.7-7.3) \mathrm{ab}$ & $4.9(4.5-5.3) \mathrm{a}$ \\
\hline
\end{tabular}

${ }^{\mathrm{z}}$ Substrate 1 (S1; primarily bark, peat, and perlite), substrate 2 (S2; primarily bark, peat, and vermiculite), substrate 3 (S3; primarily bark, peat, and coarse perlite), and substrate 4 (S4; primarily peat) and three container size treatments: \#l (2.8 L), \#3 (11.4 L), and \#5 (14.6 L). I L = 0.2642 gal. Means followed by 95\% confidence interval $(\mathrm{CI})$.

${ }^{\mathrm{y}}$ Means for substrates averaged over container size.

${ }^{x}$ Mean separation in columns with Tukey's adjusted least-squares means at $P \leq 0.05$ (lowercase letters). Two-way analysis of variance showed no significant interaction between treatments.

${ }^{\mathrm{w}}$ Means for container sizes averaged over substrate treatment.

size and grown under similar conditions as those used for the stock plant study. However, natural lighting conditions were different between Expts. 1 and 2 because of the time of year when the studies were conducted. Cuttings were taken once every 4 weeks for a total of three harvests per experiment. Instead of harvesting all suitable cuttings as we did during the stock plant experiment, we only took the three most ideal cuttings from each stock plant to use for the rooting study. For both experiments, cuttings were dipped in a liquid rooting hormone containing $500 \mathrm{ppm}$ indolebutyric acid [IBA (Dip 'N Grow, Clackamas, OR)] for $5 \mathrm{~s}$ before being placed in 72-cell plant plug trays (Preforma; Jiffy, Lorain, $\mathrm{OH}$ ) that contained a peat and coir rooting substrate with proprietary binding agents. Trays of cuttings were placed on a greenhouse bench and watered with mist nozzles (030342ll-b pcs 25 coolpro c $4 \times 75$ head + ad20; Netafim, Fresno, CA) controlled by a six-zone misting timer (NOVA 1626ET; Phytotronics, Earth City, MO). The mist timer operated $24 \mathrm{~h}$ per day and was applied in 10-s bursts every $15 \mathrm{~min}$ during the first week, every 30 min during the second week, and every $60 \mathrm{~min}$ during the third and fourth weeks. The rooting substrate was kept at $65^{\circ} \mathrm{F}$ with bottom heat mats (Redi Heat model RHD2110; Phytotronics), and air temperature was maintained between 68 and $73^{\circ} \mathrm{F}$. No supplemental lighting was provided over the mist bench.

We assessed the cuttings for rooting status by gently tugging the cutting to determine if root growth had penetrated the substrate cube. The percent of cuttings rooted was analyzed after averaging total rooted cuttings over the three harvest dates (data not presented). We also counted roots that were visible on the outside of the substrate cube to determine the vigor of root growth. The number of visible roots was analyzed by averaging over the harvest date to include all three harvests. No roots were counted above 50 because they became indistinguishable from one another.

For the rooting study, 12 cuttings were taken at each of three harvests from each substrate and container size combination for a total of 36 observations per treatment. Rooting data were averaged over the three harvest dates. Response variables for the rooting experiment included percent of cuttings rooted and average number of visible roots.

Data were analyzed using $\mathrm{R}(\mathrm{R}$ Core Team, 2016) and the lsmeans package (Fox and Weisberg, 2011); a two-way analysis of variance (ANOVA) including substrate and container size as predictor variables was also performed. Least-squares means were calculated for each response variable except percent of cuttings rooted, which was analyzed with the chisquared test to determine the association between response and predictor variables. Tukey's adjusted pairwise comparisons were considered and significant differences were noted using $\alpha=0.05$, and $95 \%$ confidence intervals were constructed.

\section{Results and discussion}

CutTings Per Plant. The number of cuttings harvested per plant was averaged over the three harvest dates before the analysis to obtain a better understanding of the overall performance of stock plants over the course of the study. During the first stock plant experiment, the main effects of substrate and container size treatments were statistically significant, although the interaction of size $\times$ substrate was not (Table 3.) Stock plants grown in S2 and S3 produced the most cuttings per plant, whereas those grown in S1 produced the fewest. Pairwise comparisons of leastsquares means showed that all substrate treatments were significantly different at $P \leq 0.05$, except for S2 and S3, which were quite similar. When data were averaged over the substrate to examine the effects of container size, stock plants grown in \# l containers produced significantly more cuttings than \#3 containers. Pairwise comparisons of other container sizes were not statistically significant, nor was the size $\times$ substrate interaction.

Larger numbers of cuttings produced by stock plants grown in S2 and $S 3$ during Expt. 1 could be due to the $\mathrm{pH}$ of those substrates (Table $\mathrm{l}$ ). Substrate 3 started and ended Expt. 1 with the lowest $\mathrm{pH}$ (5.6 and 5.3, respectively). Although S2 started with the highest $\mathrm{pH}(6.3)$, it ended with the second lowest (5.4). The other two substrates did not experience the decrease in $\mathrm{pH}$ during Expt. 1 and remained above 6.1 in both pre and post growth analyses, and may have been above the ideal range for this variety. Because $\mathrm{pH}$ directly influences nutrient availability (Bailey et al., 2012), even small changes in $\mathrm{pH}$ could cause changes in plant growth responses.

Stock plants grown in S2 may have produced more cuttings due to an initially higher level of total nitrogen (Table 1) because the substrate started Expt. 1 with the highest of the four substrates. Substrate 2 also started Expt. I with the lowest carbon-to-nitrogen ratio (13:1), which may have allowed for better nitrogen uptake because ratios above $24: 1$ can lead to nitrogen immobilization and 
nutritional deficits (Ingram, et al., 1993). Substrate 3 started Expt. I with the highest electrical conductivity (Table 1), which may have allowed for higher initial growth rates.

Although within Expt. 1 the response to the container size was statistically significant, the differences in the mean response were very small was obtained from the smallest containers (Table 3). Because this contradicts the results of container size studies performed for 'Kyoho' grape [Vitis labruscana (Xie et al., 2013)], tomato [Solanum lycopersicum (Bouzo and Favaro, 2015; Nishizawa and Saito, 1998)], scarlet sage [Salvia splendens (van Iersel, 1997)], and kiwi [Actinidia deliciosa (Tonutti and Giulivo, 1990)], among others, it is possible that the duration of the present experiment was not long enough to result in decreased growth in the smaller container sizes. It is also possible that although the data were statistically significant due to a large sample size, the differences in response may not be practically or biologically significant to the level of practitioners.

Results of the second experiment showed different trends for the container size, although the main effects of both size and substrate were statistically significant. Because Tukey adjustments for multiple testing were and the highest number of cuttings

performed, the pairwise comparisons of substrate treatment showed no significant differences; however, S2 and $S 4$ produced the most cuttings per plant (Table 3). During the second experiment, S3 had the lowest mean response, which may have been due to differences in the substrate batch, such as pH (Table l) as well as other chemical or physical differences. We found that the average number of cuttings was significantly lower in \# 1 containers compared with \#3 or \#5 containers during the second experiment (Table 3). Differences between \#3 and \#5 containers were not statistically significant, nor was the size $\times$ substrate interaction. The significant main effect of container size during Expt. 2 agrees with the results of container size studies performed for multiple species and demonstrates the typical increase in growth in larger containers (Bouzo and Favaro, 2015; Nishizawa and Saito, 1998; Tonutti and Giulivo, 1990; van Iersel, 1997; Xie et al., 2013).

Cuttings Per square Foot. The number of cuttings produced per square foot during Expt. I was dramatically higher in the \#l containers compared with the \#3 and \#5 containers (Table 4 ). Results of the first experiment revealed that the main effects of substrate and container size as well as the interaction

Table 4. Mean number of cuttings harvested per square foot from greenhousegrown 'Snow Angel' coral bells stock plants averaged over three harvest dates within Expt. 1 (Oct. 2016 to Mar. 2017) as influenced by four substrate treatments. ${ }^{\mathrm{z}}$

\begin{tabular}{|c|c|c|}
\hline Container size & Substrate & Cuttings [mean $(95 \% \mathrm{CI})$ no. $\left./ \mathrm{ft}^{2}\right]^{\mathrm{y}}$ \\
\hline \multirow[t]{4}{*}{$\# 1^{x}$} & Sl & $5.9(5.5-6.3) \mathrm{d}^{\mathrm{w}}$ \\
\hline & S2 & $7.9(7.5-8.3) b$ \\
\hline & S3 & $8.7(8.4-9.1) \mathrm{a}$ \\
\hline & S4 & $6.8(6.4-7.2) \mathrm{c}$ \\
\hline \multirow[t]{4}{*}{ \#3 } & SI & $2.5(2.1-2.9) b$ \\
\hline & S2 & $3.2(2.9-3.6) \mathrm{a}$ \\
\hline & S3 & $3.3(2.9-3.6)$ a \\
\hline & S4 & $2.9(2.5-3.3) \mathrm{ab}$ \\
\hline \multirow[t]{4}{*}{ \#5 } & SI & $2.6(2.2-3.0) \mathrm{c}$ \\
\hline & S2 & $3.4(3.0-3.8) \mathrm{ab}$ \\
\hline & S3 & $3.6(3.2-4.0) \mathrm{a}$ \\
\hline & S4 & $2.8(2.8-3.2) b c$ \\
\hline
\end{tabular}

${ }^{\mathrm{z}}$ Substrate $\mathrm{l}$ (S1; primarily bark, peat, and perlite), substrate 2 (S2; primarily bark, peat, and vermiculite), substrate 3 (S3; primarily bark, peat, and coarse perlite), and substrate 4 (S4; primarily peat) and three container size treatments: \#1 $(2.8 \mathrm{~L}), \# 3(11.4 \mathrm{~L})$, and \#5 (14.6 L); $1 \mathrm{~L}=0.2642$ gal. Means followed by $95 \%$ confidence interval (CI).

${ }^{\mathrm{y}} 1$ cutting $/ \mathrm{ft}^{2}=10.7639$ cuttings $/ \mathrm{m}^{2}$

${ }^{\mathrm{x}}$ Means for substrates averaged within each container size.

${ }^{\text {w}}$ Mean separation in columns with Tukey's adjusted least-squares means at $P \leq 0.05$ (lowercase letters). Two-way analysis of variance showed a significant interaction between treatments. of size $\times$ substrate were all significant. The significant interaction between size and substrate indicates that the response to substrate was different depending on the container size. To interpret the data better, pairwise comparisons of substrate were calculated for each container size separately. Within the \#l containers, all pairwise comparisons of substrate were significant, with S3 resulting in the highest number of cuttings per square foot and $\mathrm{SI}$ resulting in the lowest number. When comparing the effects of substrate in \#3 containers, the trends were the same. The lowest number of cuttings per square foot was produced by stock plants grown in S1, whereas those grown in S3 resulted in the highest number. The results of pairwise comparisons within \#5 containers were very similar to those of stock plants grown in S3, which produced the most cuttings per square foot, and those grown in Sl, which produced the fewest.

The second experiment showed the same trend for container size in terms of cuttings per square foot, although the interaction of size $\times$ substrate was not significant (Table 5). Similar to the first experiment, plants grown in \#1 containers produced the largest number of cuttings per square foot and differed significantly from those grown in both \#3 and \#5 containers. There was no significant difference between \#3 and \#5 containers for this parameter. The main effects of substrate showed trends that were different from those of Expt. 1. Stock plants grown in S3 resulted in the lowest response, producing significantly fewer cuttings per square foot than those grown in S4 or S2. The small differences between the highest and lowest responses (2.9 vs. 2.4 cuttings $/ \mathrm{ft}^{2}$ ) were statistically significant due to the large sample size, but they may not be practically significant to the perennial producer.

When analyzed based on cuttings per square foot, the main effects of substrate followed the same trends as analyses performed for cuttings per plant, and results can likely be explained by the same mechanisms. However, the differences between substrate are much more pronounced in the smaller containers, which could be due to more dramatic fluctuations in substrate temperature (Poorter et al., 2012) as well as 
Table 5. Mean number of cuttings harvested per square foot from greenhousegrown 'Snow Angel' coral bells stock plants averaged over three harvest dates within Expt. 2 (July to Nov. 2017) as influenced by four substrate treatments. ${ }^{2}$

\begin{tabular}{lc}
\hline Treatment & Cuttings $\left[\text { mean }(\mathbf{9 5 \%} \mathbf{C I}) \mathbf{n o .} / \mathbf{f t}^{2}\right]^{\mathbf{y}}$ \\
\hline S1 $^{\mathrm{x}}$ & $2.5(2.2-2.8) \mathrm{ab}^{\mathrm{w}}$ \\
S2 & $2.9(2.6-3.1) \mathrm{a}$ \\
$\mathrm{S} 3$ & $2.4(2.1-2.6) \mathrm{b}$ \\
$\mathrm{S} 4$ & $2.9(2.7-3.2) \mathrm{a}$ \\
$\# 1^{\mathrm{v}}$ & $3.7(3.5-4.0) \mathrm{a}$ \\
$\# 3$ & $2.1(1.8-2.3) \mathrm{b}$ \\
$\# 5$ & $2.2(2.0-2.4) \mathrm{b}$ \\
\hline
\end{tabular}

${ }^{\mathrm{z}}$ Substrate $\mathrm{l}$ (S1; primarily bark, peat, and perlite), substrate 2 (S2; primarily bark, peat, and vermiculite), substrate 3 (S3; primarily bark, peat, and coarse perlite), and substrate 4 (S4; primarily peat) and three container size treatments: \#1 $(2.8 \mathrm{~L}), \# 3(11.4 \mathrm{~L})$, and \#5 $(14.6 \mathrm{~L}) ; 1 \mathrm{~L}=0.2642$ gal. Means followed by $95 \%$ confidence interval $(\mathrm{CI})$.

${ }^{\mathrm{y}} 1$ cutting $/ \mathrm{ft}^{2}=10.7639$ cuttings $/ \mathrm{m}^{2}$

${ }^{\mathrm{x}}$ Means for substrates averaged over container size.

"Mean separation in columns with Tukey's adjusted least-squares means at $P \leq 0.05$ (lowercase letters). Two-way analysis of variance showed no significant interaction between treatments.

${ }^{\mathrm{v}}$ Means for container sizes averaged over substrate treatment.

air and water-holding capacities that differ with container height and width (Bilderback and Fonteno, 1987). Despite an increase in the number of cuttings per plant in the larger container sizes, the magnitude of difference was not enough to compensate for the amount of space taken by the larger containers during the time period of this study.

MEAN FRESH WEIGHT OF CUTTINGs. Although all the mean fresh weights of cuttings from Expt. $\mathrm{l}$ were between 3.0 and $4.0 \mathrm{~g} /$ cutting with seemingly very low variability, even small differences can be practically significant when it comes to the quality of a cutting and how well it will root. The results of ANOVA testing of the data averaged over the harvest date showed that the main effects of substrate were significant, but that neither container size nor the interaction of size $\times$ substrate were statistically significant; therefore, only data related to substrate effects are presented here. When averaging over the container size, the highest fresh weight per cutting was from stock plants grown in S3, although the response to $S 2$ was very similar (Table 6). Stock plants grown in substrates 2 and 3 produced cuttings that were significantly larger than those from plants grown in S1, which had the lowest mean response.

Substrate analyses showed that S2 started with more than twice the total nitrogen found in the other substrates before planting, which could have led to larger biomass. Although this explanation does not hold true for the increased response to S3, which had the lowest starting level of nitrogen, it also had the lowest starting $\mathrm{pH}$ (5.6 vs. 6.1-6.3) (Table 1), which could have allowed for better availability of some essential nutrients (Bailey et al., 2012).

The second experiment showed different trends when examining pairwise comparisons of mean fresh weight. Just as in Expt. 1, size and size $\times$ substrate were not significant for data averaged over the harvest date, but the main effects of substrate were significant. Pairwise comparisons showed that all substrates were significantly different except for S1 and $S 3$, which had the lowest mean responses (Table 6). Substrate 4 had the highest mean response, and the average fresh weight per cutting was significantly higher than those of all other substrate treatments.

Substrate analyses before planting suggest that $S 4$ may have produced larger cuttings initially because of a more ideal starting $\mathrm{pH}$ (Table $\mathrm{l}$ ) that allowed for better nutrient availability (Bailey et al., 2012). It could also be partially due to the higher total nitrogen and lower ammonium:nitrate ratio, which has been shown to increase stem dry weight in pepper [Capsicum annuum (BarTal et al., 2001)]. Before being planted, S4 also had the lowest carbon-to-nitrogen $(\mathrm{C}: \mathrm{N})$ ratio (41.25), which can influence nitrogen availability. When substrate ratios exceed $24: 1$, indicating there is more carbon present, it results in nitrogen immobilization and can lead to nutritional deficits (Ingram et al., 1993). Although the $\mathrm{C}: \mathrm{N}$ ratio of $\mathrm{S} 4$ was still considered higher than ideal, it was the lowest of the substrates used in this experiment.

Percent of rooted cuttings. The percent of cuttings that rooted during our rooting study was averaged over three harvests (data not presented). Data were subjected to a chi-square test to determine if there was an association between rooting status and stock plant treatment.

The results of Expts. 1 and 2 showed no significant association between treatment and rooting status after 4 weeks on the mist bench. The first experiment resulted in $98 \%$ to $100 \%$ rooting. The second experiment resulted in $100 \%$ rooted cuttings regardless of treatment.

Average number of Visible ROоTs. The results of Expt. 1 showed that after 4 weeks, both container size and substrate main effects were significant, although the interaction of size $\times$ substrate was not. Pairwise comparisons of container size were all significant when averaging over the substrate type, with \#5 containers producing the largest number of visible roots and \#l containers producing the fewest (Table 7). Response to stock plant container size indicates that cuttings taken from \#5 containers rooted more successfully. This could be due to better overall health of stock plants as they aged, resulting in cuttings with higher nutrient and carbohydrate contents. Zerche and Druege (2009) demonstrated that increased levels of sucrose and total sugar content in the leaves of cuttings as well as increased tissue nitrogen levels were correlated with an increase in total root length of poinsettia (Euphorbia pulcherrima) cuttings.

When averaged over the container size, plants grown in S4 produced the largest number of roots, whereas those grown in S2 produced the fewest (Table 7). The first batch of S4 used during Expt. 1 had the highest percent organic matter, whereas S2 had the lowest, both before and after growth analyses (Table 1). Substrate 4 also had the highest starting cation exchange capacity, although the postanalysis showed that all four substrates were very similar by the end of the experiment (Table 1). These factors may have had a role in producing more vigorous 
Table 6. Mean fresh weight of cuttings harvested from greenhouse-grown 'Snow Angel' coral bells stock plants averaged over three harvest dates within Expt. 1 (Oct. 2016 to Mar. 2017) and Expt. 2 (July to Nov. 2017) as influenced by four substrate treatments. ${ }^{\mathrm{z}}$

\begin{tabular}{llr}
\hline & \multicolumn{1}{c}{ Expt. 1 } & \multicolumn{1}{c}{ Expt. 2 } \\
\cline { 2 - 3 } Treatment & \multicolumn{1}{c}{ Cutting fresh wt [mean $\mathbf{( 9 5 \% ~ C I ) ~ g ] ^ { \mathrm { y } }}$} \\
\hline S1 ${ }^{\mathrm{x}}$ & $3.4(3.3-3.6) \mathrm{b}^{\mathrm{w}}$ & $3.7(3.5-3.9) \mathrm{c}$ \\
S2 & $3.7(3.6-3.9) \mathrm{a}$ & $4.0(3.8-4.2) \mathrm{b}$ \\
S3 & $3.8(3.6-3.9) \mathrm{a}$ & $3.7(3.5-3.8) \mathrm{c}$ \\
S4 & $3.6(3.4-3.7) \mathrm{ab}$ & $4.4(4.2-4.6) \mathrm{a}$ \\
\hline
\end{tabular}

${ }^{\mathrm{z}}$ Substrate $\mathrm{l}$ (S1; primarily bark, peat, and perlite), substrate 2 (S2; primarily bark, peat, and vermiculite), substrate 3 (S3; primarily bark, peat, and coarse perlite), and substrate 4 (S4; primarily peat). Means followed by $95 \%$ confidence interval (CI).

${ }^{\mathrm{y}} \mathrm{lg}=0.0353 \mathrm{oz}$

${ }^{\mathrm{x}}$ Means for substrates averaged over container size.

"Mean separation in columns with Tukey's adjusted least squares means at $P \leq 0.05$ (lowercase letters). Two-way analysis of variance showed no significant main effect of container size and no significant interaction between substrate and container size.

Table 7. Mean number of roots produced by cuttings from greenhouse-grown 'Snow Angel' coral bells stock plants after 4 weeks under mist averaged over harvest date within Expt. 1 (Mar. to May 2017) and Expt. 2 (Nov. 2017 to Jan. 2018 ) as influenced by four substrate treatments. ${ }^{z}$

\begin{tabular}{|c|c|c|}
\hline \multirow[b]{2}{*}{ Treatment } & Expt. 1 & Expt. 2 \\
\hline & \multicolumn{2}{|c|}{ Visible roots [mean $(95 \% \mathrm{CI})$ no./cutting] } \\
\hline$S 1^{y}$ & $39.3(36.3-42.2) a b^{x}$ & $46.6(44.6-48.6) \mathrm{a}$ \\
\hline S2 & $36.8(33.9-39.8) b$ & $44.0(42.0-46.1) \mathrm{a}$ \\
\hline S3 & $41.0(38.1-44.0) \mathrm{ab}$ & $46.1(44.0-48.1) \mathrm{a}$ \\
\hline S4 & $44.0(41.1-47.0) \mathrm{a}$ & $44.8(42.7-46.8) \mathrm{a}$ \\
\hline$\# 1^{\mathrm{w}}$ & $33.9(31.3-36.5) \mathrm{c}$ & $48.4(46.7-50.2) \mathrm{a}$ \\
\hline \#3 & $39.5(37.0-42.1) b$ & $45.1(43.4-46.8) b$ \\
\hline$\# 5$ & $47.5(44.9-50.0) \mathrm{a}$ & $42.6(40.9-44.3) \mathrm{b}$ \\
\hline
\end{tabular}

${ }^{\mathrm{z}}$ Substrate 1 (S1; primarily bark, peat, and perlite), substrate 2 (S2; primarily bark, peat, and vermiculite), substrate 3 (S3; primarily bark, peat, and coarse perlite), and substrate 4 (S4; primarily peat) and three container size treatments: \#1 (2.8 L), \#3 (11.4 L), and \#5 (14.6 L); $1 \mathrm{~L}=0.2642$ gal. Means followed by $95 \%$ confidence interval (CI).

${ }^{\mathrm{y}}$ Means for substrates averaged over container size.

${ }^{x}$ Mean separation in columns with Tukey's adjusted least squares means at $P \leq 0.05$ (lowercase letters). Two-way analysis of variance showed no significant interaction between substrate and container size.

${ }^{w}$ Means for container sizes averaged over substrate treatment.

root growth in cuttings, although more data need to be collected to understand the primary mechanism behind these results.

When the statistical analysis was performed for the number of visible roots produced during Expt. 2, more dramatic trends were discovered than when simply looking at the rooting status. After 4 weeks under mist, the main effect of the container size was statistically significant, with cuttings from \#l containers producing the largest number of visible roots and cuttings from \#5 containers producing the fewest (Table 7).

These results contradict those of Expt. 1, which showed that a significant increase in the number of visible roots was correlated with an increase in the container size. Because there it is possible to make some recommendations to perennial propagators for stock plant care and rooting of 'Snow Angel' coral bells. Based on the research conducted, stock plants would likely perform best in a well-drained substrate with physical properties similar to that of $\mathrm{S} 3$ with a fairly low $\mathrm{pH}$ (possibly between 4.7 and 5.6). For the initial 6 months after starting a new stock plant from a cutting, it is much more efficient to grow them in \# 1 containers because the larger containers do not provide enough advantages to justify the space they occupy. Because our data did not extend over a longer period of time, no claims can be made about the longevity of a stock plant in relation to the container size or substrate in which it is grown. Because more cuttings were produced during the first experiment regardless of stock plant treatment, it may be advantageous to maintain daytime greenhouse temperatures between 65 and $73^{\circ} \mathrm{F}$ and nighttime temperatures between 61 and $73^{\circ} \mathrm{F}$. Because rooting rates were near $100 \%$ for all treatment combinations during both rooting experiments, we can confidently recommend using our cutting and propagation protocol for the rooting of 'Snow Angel' basal cuttings.

\section{Literature cited}

Adam, S.A., Jr. 2005. Nutrition and management of perennial stock plants. Combined Proc. Intl. Plant Prop. Soc. 55: 348-355.

Albrecht, M.L. and D.M. Crockett. 1994. Photoperiod influences vegetative growth of Heuchera cultivars (Saxifragaceae). Trans. Kans. Acad. Sci. 71:4-12.

was an opposite correlation found in Expt. 2, and because the results of Expts. 1 and 2 did not agree, it is possible that environmental factors such as greenhouse temperature, day length, supplemental lighting, and shade may have altered the plants' performance. The second experiment was completed during the winter months and greenhouse temperatures were lower, which could have allowed stock plants in the smaller containers to avoid some of the stresses associated with smaller container volumes such as extreme temperature fluctuations of the root zone and more accelerated water depletion (Poorter et al., 2012).

\section{Conclusions}

Despite some discrepancies between the first and second experiment,
Bailey, D.A., P.V. Nelson, and W.C. Fonteno. 2012. Substrate $\mathrm{pH}$ and water quality. 16 Nov. 2017. <http://www. nurserycropscience.info/water/sourcewater-quality/other-references/ substrate-ph-and-water-quality.pdf $>$.

Bar-Tal, A., B. Aloni, L. Karni, and R. Rosenberg. 2001. Nitrogen nutrition of greenhouse pepper. ii. Effects of nitrogen concentration and $\mathrm{NO}_{3}: \mathrm{NH}_{4}$ ratio on growth, transpiration, and nutrient uptake. HortScience 36:1252-1259.

Bilderback, T.E. and W.C. Fonteno. 1987. Effects of container geometry and media physical properties on air and water volumes in containers. J. Environ. Hort. 5:180-182. 
Bouzo, C.A. and J.C. Favaro. 2015. Container size effect on the plant production and precocity in tomato (Solanum lycopersicum L.). Bulg. J. Agr. Sci. $21: 325-332$.

Fox, J. and S. Weisberg. 2011. An $\{R\}$ companion to applied regression. 2 nd ed. 29 Aug. 2016. <http://socserv.socsci. mcmaster.ca/jfox/Books/Companion>.

Gabriel, M.Z., J.E. Atland, and J.S. Owen, Jr. 2009. The effect of physical and hydraulic properties of peat moss and pumice on douglas fir bark based soilless substrates. HortScience 44:874-878.

Gibson, J.L. and C.B. Cerveny. 2005. Stock plant production and management basics for small greenhouse businesses. Univ. Florida IFAS Ext. ENH1021. 10 Oct. 2017. <http://ufdcimages.uflib.ufl. $\mathrm{edu} / \mathrm{IR} / 00 / 00 / 17 / 42 / 00001 /$ EP28400.pdf>.
Ingram, D.L., R.W. Henley, and T.H. Yaeger. 1993. Growth media for container grown ornamental plants. Univ. Florida Coop Ext Serv. Bul. 241.

Nishizawa, T. and K. Saito. 1998. Effects of rooting volume restriction on the growth and carbohydrate concentration in tomato plants. J. Amer. Soc. Hort. Sci. 123:581-585.

NeSmith, D.S. and J.R. Duval. 1998. The effect of container size. Hort Technology 8:495-498.

Poorter, H., F. Fiorani, M. Stitt, U. Schurr, A. Finck, Y. Gibon, B. Usadel, R. Munns, O.K. Atkin, F. Tardieu, and T.L. Pons. 2012. The art of growing plants for experimental purposes: A practical guide for the plant biologist. Funct. Plant Biol. 39:821-838.

R Core Team. 2016. R: A language and environment for statistical computing. 29
Aug. 2016. <https://www.R-project. $\operatorname{org} />$.

Tonutti, P. and C. Giulivo. 1990. Effect of available soil volume on growth of young kiwi plants. Acta Hort. 282:283290.

van Iersel, M. 1997. Root restriction effects on growth and development of salvia (Salvia splendens). HortScience 32:11861190.

Xie, Z., X. Guo, and H. Cao. 2013. Effect of root restriction on vegetative growth and leaf anatomy of 'Kyoho' grapevines cultivar. Afr. J. Agr. Res. 8:1304-1309.

Zerche, S. and U. Druege. 2009. Nitrogen content determines adventitious rooting in Euphorbia pulcherrima under adequate light independently of prerooting carbohydrate depletion of cuttings. Scientia Hort. 121:340-347. 